\title{
Photocatalytic Degradation of Textile dye Orange-122 Via Electrospray Mass Spectrometry
}

\section{Luiz Eduardo Nochi de Castro ${ }^{1^{*}}$}

https://orcid.org/0000-0002-5968-8968

Eduardo César Meurer ${ }^{1}$

https://orcid.org/0000-0003-4835-7773

\author{
Helton José Alves ${ }^{2}$ \\ https://orcid.org/0000-0001-6942-1020
}

\author{
Marco Aurélio Reis dos Santos 1 \\ https://orcid.org/0000-0002-8876-8502 \\ Erika de Castro Vasques ${ }^{1}$ \\ https://orcid.org/0000-0002-6669-9745 \\ Leda Maria Saragiotto Colpini ${ }^{1}$
https://orcid.org/0000-0003-3660-188X
}

${ }^{1}$ Federal University of Parana, Campus Avançado de Jandaia do Sul, Jandaia do Sul, Brazil; ${ }^{2}$ Federal University of Parana, Setor Palotina, Palotina, Brazil.

Received: 2018.11.12; Accepted: 2020.03.17.

*Correspondence: luiz_nc@yahoo.com; Tel.: +55-43-996750525 (L.E.N.C.).

\section{HIGHLIGHTS}

- Photocatalysis is an efficient method for Orange-122 discoloration.

- ESI-MS instrument is highly desirable to screen photocatalytic degradation of dye.

- Surface response data treatment, demonstrating be a great tool for discoloration data.

\begin{abstract}
This work reports the study of the potential application of $\mathrm{Zn} / \mathrm{TiO}_{2}$ catalysts, obtained by the solgel method, in processes of environmental decontamination through the reactions of photodegradation of textile dye, followed by electrospray mass spectrometry. The catalysts synthesis was performed according to a $2^{2}$ factorial design with repetition at the central point. The characterization techniques used were: $\mathrm{N}_{2}$ adsorption measurements (BET method), scanning electron microscopy with energy dispersive X-ray (MEV/EDS), X-ray diffraction and point of zero charge (PZC). The photocatalytic tests were performed in batch in the presence of sunlight, and to evaluate the degradation kinetics study, a rapid direct injection electrospray mass spectrometry (DI-ESI-MS) method has been developed. By the photocatalytic tests, the calcination temperature of $400{ }^{\circ} \mathrm{C}$ has shown the best results of discoloration for the reactive Orange-122 dye $(99.76 \%)$ in a reaction time of $2 \mathrm{~h}$. The discoloration kinetics were a pseudo-first order, and a statistical analysis was performed to investigate the effects of the variables and to optimize the conditions of discoloration to the dye. After the reactional time of $2 \mathrm{~h}$, an ion of $\mathrm{m} / \mathrm{z} 441.5$ was detected by ESI-MS, indicating that the photocatalytic process was effective for the degradation of the dye to secondary compounds.
\end{abstract}

Keywords: heterogeneous photocatalysis; sol-gel; $\mathrm{Zn} / \mathrm{TiO}_{2}$; characterization; discoloration.

\section{INTRODUCTION}

Synthetic dyes are extremely commonly used in the textile industry, and the discarding of these effluents is a serious environmental problem [1]. Annually, 700,000 tons of dyes, bleaches and pigments are produced 
around the world, but only $20 \%$ of them are used in the textile industry and end the process; the rest is destined as effluent [2].

The reactive Orange-122 dye are one of the typical effluents of textile industries which present a highly recalcitrant residue, which makes their degradation more difficult, in the vast majority of cases due to an incomplete fixation of the dye in the fabric fiber [3]. In the majority, the dyes are toxic, carcinogenic and not biodegradable, inhibiting the process of biological treatment, and they have to be removed before discard in aquatic bodies [4].

Many chromophores groups are used in dye synthesis; however, the most often used group currently belongs to the class of azo dyes (-N=N-). These constitute about $50-70 \%$ of all dyes used in the textile industry. Depending on the number of azo bonds present in the structure, these dyes can be classified as monoazo, diazo, triazo and so forth [5].

Therefore, the discarding of colorful effluents in the ecosystem is a dramatic source of aesthetic pollution, eutrophication and disturbances in aquatic life. The necessity of effective treatments is becoming an increasing concern to minimize environmental problems $[6,7]$.

Due to the nature of these effluents, conventional biological treatments are ineffective as much in regard to the discoloration as to the effluent degradation. During the last decades, there has been a growing interest in the use of advanced oxidative processes (AOPs) as the most effective method for the elimination of gaseous and liquid pollutants [1].

The use of AOPs is increasingly becoming an attractive method due to its numerous applications, especially in the treatment of effluents that contain toxic compounds and/or refractories. The AOPs offer efficient degradation of the effluents, instead of simply changing them in phase, as occurs in other processes, whether of coagulation/flocculation, filtration or adsorption [4].

Heterogeneous photocatalysis, which belongs to this breed, is a technology of emerging degradation that promotes the total degradation of organic pollutants to innocuous compounds, such as water and carbon dioxide, through semiconductor metals in the form of catalysts. Among all of the semiconductors, titanium dioxide $\left(\mathrm{TiO}_{2}\right)$ is one of the most studied, due to its high degree of photochemical stability in a large range of $\mathrm{pH}$, low cost and non-toxicity [3].

A strategy to improve the efficiency of the photocatalyst is the production of mixed oxides with doping of different metals, such as metal/ $/ \mathrm{TiO}_{2}$, as in the case of $\mathrm{Zn} / \mathrm{TiO}_{2}$. This has shown some positive characteristics, as an increase in the surface area of the support, improvement of porous structure and for presenting gap energy close to that of $\mathrm{TiO}_{2}$; however, further studies are needed to evaluate its efficiency and viability [8].

Thus, the main objective of this work was the study of the potential for applying catalysts of $\mathrm{Zn} / \mathrm{TiO}_{2}$, obtained by the sol-gel method, in processes of environmental decontamination through photodegradation reactions of the reactive Orange-122 dye, followed by electrospray mass spectrometry.

\section{MATERIALS AND METHODS}

\section{Catalysts preparation}

The following catalysts were synthesized: $\mathrm{TiO} 2$ and $\mathrm{Zn} / \mathrm{TiO} 2$ by the sol-gel method, in the latter of which the metal load of $\mathrm{Zn}$ was varied between $2 \%, 6 \%$ and $10 \%(\mathrm{~m} \mathrm{~m}-1)$, with the goal of studying the effects of the variables $\mathrm{Zn}$ and calcination temperature in the process of dye discoloration through a factorial experiment in two levels $\left(2^{2}\right)$.

The two levels, high and low, with regard to the concentration level of $\mathrm{Zn}(\%)$ and calcination temperature $\left({ }^{\circ} \mathrm{C}\right)$, are specified in Table 1.

Table 1. Control variables considered in $2^{2}$ factorial design.

\begin{tabular}{|c|c|c|c|}
\hline Variable & Low Level & $\begin{array}{c}\text { Central point } \\
(\bullet)\end{array}$ & $\begin{array}{c}\text { High Level } \\
(+)\end{array}$ \\
\hline $\begin{array}{c}\text { Calcination Temp. } \\
\% \text { Zn }\end{array}$ & $200^{\circ} \mathrm{C}$ & $\begin{array}{c}300^{\circ} \mathrm{C} \\
6\end{array}$ & $\begin{array}{c}400^{\circ} \mathrm{C} \\
10\end{array}$ \\
\hline
\end{tabular}

Furthermore, to obtain a second-order response surface model, a central point was added in this experimental design. The central point was replicated three times with the objective of estimating the residual error. Thus, a total of seven experiments was performed, as shown in Table 2. 
Table 2. Factorial design data $\left(2^{2}\right)$ with addition of the central point.

\begin{tabular}{ccc}
\hline Experiment & Zn\% & $\begin{array}{c}\text { Calcination } \\
\text { Temperature }\end{array}$ \\
\hline 1 & - & - \\
2 & - & + \\
3 & + & - \\
4 & + & + \\
5 & - & $\cdot$ \\
6 & - & $\cdot$ \\
7 & - & $\cdot$ \\
\hline
\end{tabular}

A geometrical representation of the complete factorial design $\left(2^{2}\right)$ with the central point addition is illustrated in Figure 1. Note that each vertex of the figure is represented as a result of the experiment, with the horizontal axis representing the variable $\mathrm{Zn}$ and the vertical axis, the variable Calcination Temperature. The value 90.57 in the center of the picture is the average of the results obtained with the central point.

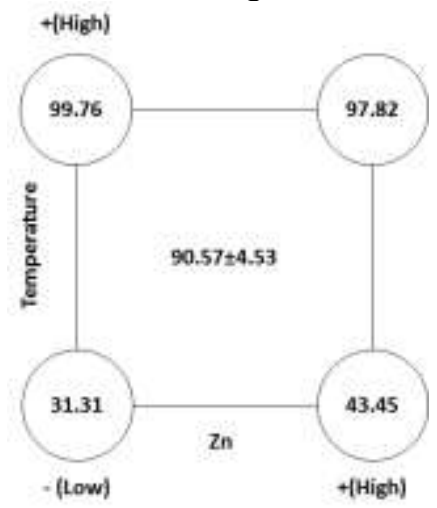

Figure 1. Geometric vision of $2^{2}$ design.

\section{Catalysts synthesis}

The $\mathrm{TiO}_{2}$ and $\mathrm{Zn} / \mathrm{TiO}_{2}$ catalysts were prepared by the sol-gel method using the molar ratio nwater:nalkoxide:nacid $=2.4: 1: 0.08$, according to $[9,10]$. Titanium (IV) isopropoxide $(\geq 97 \%$, Sigma-Aldrich $\AA$ ) and Zinc chloride (II) ( $\geq 97 \%$, Reatec $\AA)$ were used as metallic precursors, and ultra-pure Milli-Q® water (resistivity of $18 \mathrm{M} \Omega \mathrm{cm}$ ), nitric acid (Anhydrol $\circledast$ with a purity of at least $65 \%$ ) and ethyl alcohol (Nuclear $\circledast$ PA of $99.5 \%$ ) were used in the synthesis process.

Two solutions were prepared. The first was constituted by the alkoxide precursor and ethyl alcohol, under inert atmosphere of nitrogen $\left(\mathrm{N}_{2}\right)$. Alongside this, the second solution, consisting of nitric acid, water and ethyl alcohol, was prepared.

The second solution was stirred for $5 \mathrm{~min}$ and was added to the first solution via addition funnel, still under inert atmosphere. In less than $15 \mathrm{~s}$, the gel was formed, which was aged for one night.

The gel was washed for 4 days, 3 times per day with a mixture of water:acetone (1:1) to remove reagent residues. In the end, the material was dried in a rotating evaporator at $40-90^{\circ} \mathrm{C}$ for $1 \mathrm{~h}$ and later under high vacuum ( 10-3 atm) at $80^{\circ} \mathrm{C}$ for $8 \mathrm{~h}$.

The catalysts syntheses $2 \% \mathrm{Zn} / \mathrm{TiO}_{2}, 6 \% \mathrm{Zn} / \mathrm{TiO}_{2}$ and $10 \% \mathrm{Zn} / \mathrm{TiO}_{2}$ were practically the same as the $\mathrm{TiO}_{2}$ synthesis. The differences were: the addition of precursor salt of $\mathrm{Zn}$, added in different metallic masses to the second solution, and the absence of the acetone:water washing step. The drying of the catalysts was performed in a similar way to the $\mathrm{TiO}_{2}$ catalyst.

In order to obtain the precursor oxides, all catalysts were submitted to a heat treatment of calcination. The materials were calcined in temperatures of 200,300 and $400{ }^{\circ} \mathrm{C}$ with heating ramp for $5 \mathrm{~h}$ to avoid the sintering of the material.

\section{Characterization of catalysts}

\section{$\mathrm{N}_{2}$ adsorption measurements}

$\mathrm{N}_{2}$ adsorption measurements: specific surface area (So), average pore volume $(\mathrm{Vp})$, and average pore diameter ( $\mathrm{dp}$ ) of the catalysts obtained were determined in a Quantachrome Corporation model Nova 2000. 
The So values were determined by the Brunauer, Emmett, and Teller (B.E.T) method by submitting the samples to previous activation at $150{ }^{\circ} \mathrm{C}$ in vacuum for $3 \mathrm{~h}$.

Scanning electron microscopy (SEM) with energy dispersive $X$-ray (SEM/EDS)

Micrographs of the catalysts were obtained in a Scanning Electron Microscope TESCAN VEGA3, equipped with an energy dispersive X-ray microsound (EDS) Penta FET Precision by OXFORD INSTRUMENTS. The samples were fixed to the surface of a double-face adhesive tape and coated with a gold layer (5 nm, $35 \mathrm{~mA})$.

\section{Point of zero charge (PZC)}

For determination of point of zero charge, approximately $1 \mathrm{~g}$ of catalyst was weighed, diluted in $30 \mathrm{~mL}$ of distilled water and shaken with a magnetic stirrer for $24 \mathrm{~h}$ [11]. After that time, the $\mathrm{pH}$ of the suspension was determined by using a pH meter (LUCA-210) from Luca-Tec.

\section{$X$-ray diffraction}

Diffractograms of the catalysts were obtained with a Shimadzu XRD 7000 apparatus. Copper emission line ( $\mathrm{Cu} \mathrm{Ka}, \lambda=1.54056 \AA$ ) with emission tube acceleration of $30 \mathrm{kV}$, current of $20 \mathrm{~mA}$, and scanning velocity of $2^{\circ} 2 \theta$ min- 1 was used as a radiation source.

\section{Photocatalytic tests}

\section{Dye discoloration under sunlight}

The reactive textile dye used in the experiments was obtained from Texpal Química Ltda, located in Valinhos, São Paulo, Brazil and its chemical structure is presented at Figure 2. The reactive Orange-122 dye has molar mass of $1034.3 \mathrm{~g} \mathrm{~mol}-1$. Figure 3 illustrates the system used.

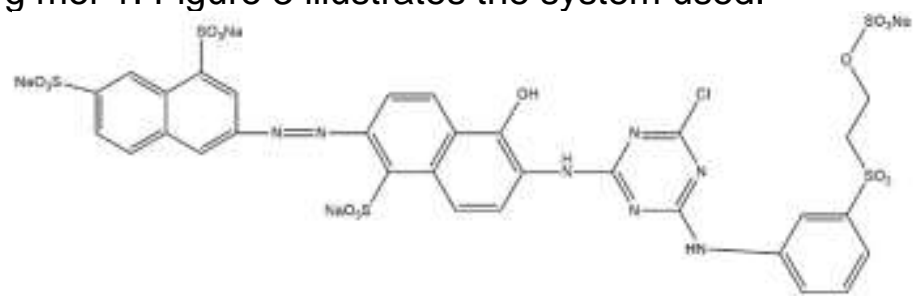

Figure 2. Structure proposed for reactive Orange-122 dye.
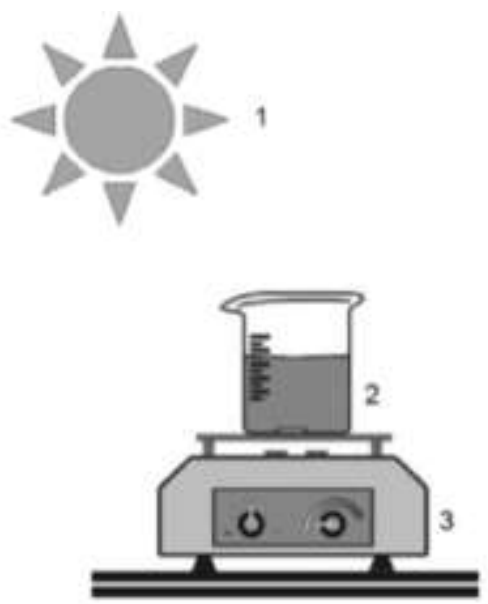

1 - Solar light

2 - Dye solution

3 - Magnetic Stirrier

Figure 3. Schematic diagram of the photocatalytic reactor [3].

The experimental system of a reactor consisted of a tank-type reactor (batch system), constituted of a cylindrical vessel (beaker) with a capacity of $250 \mathrm{~mL}$ and a magnetic stirrer to ensure the homogenization of the samples during the experiment period $(2 \mathrm{~h})$. During the discoloration tests with each catalyst, suspensions containing $150 \mathrm{~mL}$ of aqueous solution of $10 \mathrm{mg} \mathrm{L}-1$ dye and $50 \mathrm{mg}$ of each catalyst were irradiated with sunlight. After reaction times of $0,30,60,90$ and $120 \mathrm{~min}$, aliquots were collected for further analysis of discoloration and degradation. The aliquots were vacuum filtered over cellulose ester membranes $47 \mathrm{~mm}$ in diameter and $0.45 \mu \mathrm{m}$ of porosity and stored in a refrigerator. The photocatalysts tests were performed on 
March 7 and 8, 2017, from 1:30 pm to $3: 30 \mathrm{pm}$, during which time the average solar radiation was measured through a UV radiation meter in the range of 390 to $1100 \mathrm{~nm}$ (Model LI-200, SIMEPAR / Brazil) and ranged from 926.8 to $1014.0 \mathrm{~W} \mathrm{~m}^{-2}$.

The percentage of discoloration of the solution as a function of time was determined with a UV spectrophotometer, model EEQ-9006 of the brand Astral Científica, at the wavelength of $486 \mathrm{~nm}$. The absorbance was measured and the concentrations were established by the calibration curve method. The discoloration percentages were calculated by using Equation (1) below.

$$
\% \text { Discoloration }=\frac{\mathrm{C}_{0}-\mathrm{C}}{\mathrm{C}_{0}} * 100
$$

Where $\mathrm{C}_{0}$ is the dye concentration before the test $\left(\mathrm{mg} \mathrm{L}^{-1}\right)$ and $\mathrm{C}$ is the dye concentration after the test $\left(\mathrm{mg} \mathrm{L}^{-1}\right)$.

\section{Discoloration kinetics}

To evaluate the discoloration kinetics, the model of pseudo-first order of Langmuir-Hinshelwood was used, as shown in Equation (2). Many experimental results showed that Langmuir-Hinshelwood kinetics model are the most suitable for the oxidation rates of photocatalysis of various compounds in the heterogeneous system under solar illumination using $\mathrm{TiO}_{2}$ and $\mathrm{Zn} / \mathrm{TiO}_{2}$ as catalysts [12]:

$$
\mathrm{r}=-\frac{\mathrm{dC}}{\mathrm{dt}}=\frac{\mathrm{k}_{1} * \mathrm{k}_{2} * \mathrm{C}}{1+\left(\mathrm{k}_{2} * \mathrm{C}\right)}
$$

Where $r$ is the oxidation rate $\left(\mathrm{mg} \mathrm{L}^{-1} \mathrm{~min}^{-1}\right), \mathrm{C}$ is the concentration of the reactant $\left(\mathrm{mg} \mathrm{L}^{-1}\right), \mathrm{k} 1$ is the adsorption constant of the reactant $\left(\mathrm{L} \mathrm{mg}^{-1}\right)$ and $\mathrm{k}_{2}$ is the reaction rate constant $\left(\mathrm{mg} \mathrm{L}^{-1} \mathrm{~min}^{-1}\right)$. Considering that the initial concentration of the compound to be oxidized is small enough, the term $\left(\mathrm{k}_{2} . \mathrm{C}\right)$ is close to zero. Then the Equation (2) can be simplified to a pseudo-first-order Equation:

$$
-\frac{\mathrm{dC}}{\mathrm{dt}}=\mathrm{k}_{1} * \mathrm{k}_{2} * \mathrm{C}=\mathrm{k} * \mathrm{C}
$$

Where $\mathrm{k}$ is defined as a pseudo-first-order rate constant that represents the product of $\mathrm{k}_{1}$ and $\mathrm{k}_{2}$. Thus, a kinetic Equation of the pseudo-first order rate can be obtained by integrating the above equation, resulting in:

$$
\ln \frac{\mathrm{C}}{\mathrm{C}_{0}}=-(\mathrm{k} * \mathrm{t})
$$

Where $\mathrm{k}$ is pseudo-first-order rate constant, $\mathrm{t}$ is the reaction time, $\mathrm{C}$ is the compound concentrations time $t$ and $C_{0}$ is the initial compound concentrations. The slope of the plot of $\ln \left(C / C_{0}\right)$ versus time, results in the value of the rate constant $\mathrm{k}\left(\mathrm{min}^{-1}\right)$.

\section{Statistical Analysis}

The results of data treatments were obtained by using the software MINITAB® 14.0 , in which the significance level of the effects of the factors and interaction were statically tested through ANOVA at a level $\alpha$ of significance of 0.05 .

\section{Dye degradation}

The analyzes of the dye and degraded solutions were performed in a positive ion mode by direct injection into a PREMIER / XE® Quattro MicroTM API with electrospray ionization (DI-ESI-MS). The optimized parameters used during the experiment were: capillary voltage of $3 \mathrm{kV}$; cone voltage of $35 \mathrm{~V}$, source temperature of $100{ }^{\circ} \mathrm{C}$; desolvation temperature of $300^{\circ} \mathrm{C}$; desolvation gas flow of $500 \mathrm{~L} \mathrm{~h}^{-1}$; cone gas flow of $0 \mathrm{~L} \mathrm{~h}^{-1}$; mass range of $\mathrm{m} / \mathrm{z} 50$ to $\mathrm{m} / \mathrm{z} 1200$. Therefore, a scanning methodology MS of the ions directly transferred from the degradation solutions.

These parameters were optimized in preliminary experiments to obtain a greater abundance of protonated target ions. $\mathrm{N}_{2}$ was used as drying gas and as nebulizer gas. The direct injection $(5 \mu \mathrm{L})$ of the samples in the mass spectrometer was performed using rheodyne of the equipment and delivered by a pump (Thermo Scientific Finnigan Surveyor LC Pump Plus) with $200 \mu \mathrm{L} \cdot \mathrm{min}^{-1}$ flow. All the samples were analyzed 
in positive mode using formic acid as organic modifier. The approximate time of the analysis was 2 min each, and the ionic abundance of the target ion was monitored during the entire experiment, being used as indicative parameter of the reactive Orange-122 dye degradation. The sample preparation was performed according to the scheme depicted in Figure 4:

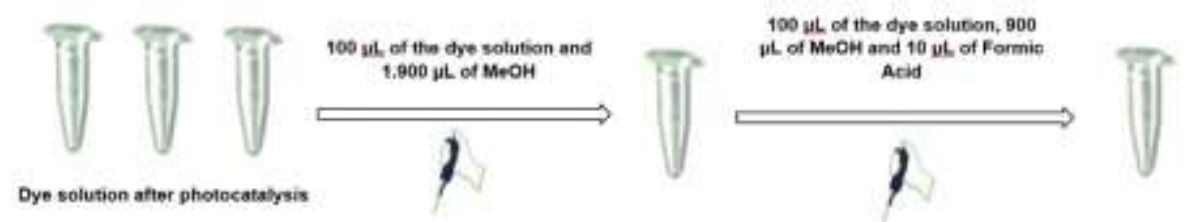

Figure 4. Preparation of sample for direct injection in mass spectrometer.

\section{RESULTS AND DISCUSSION}

\section{$\mathrm{N}_{2}$ adsorption measurements}

Figure 5 shows the $\mathrm{N}_{2}$ adsorption-desorption isotherms for the materials calcined at $400{ }^{\circ} \mathrm{C}$, with the exception of the $6 \% \mathrm{Zn} / \mathrm{TiO}_{2}$ catalyst, where the calcination temperature was $300{ }^{\circ} \mathrm{C}$.
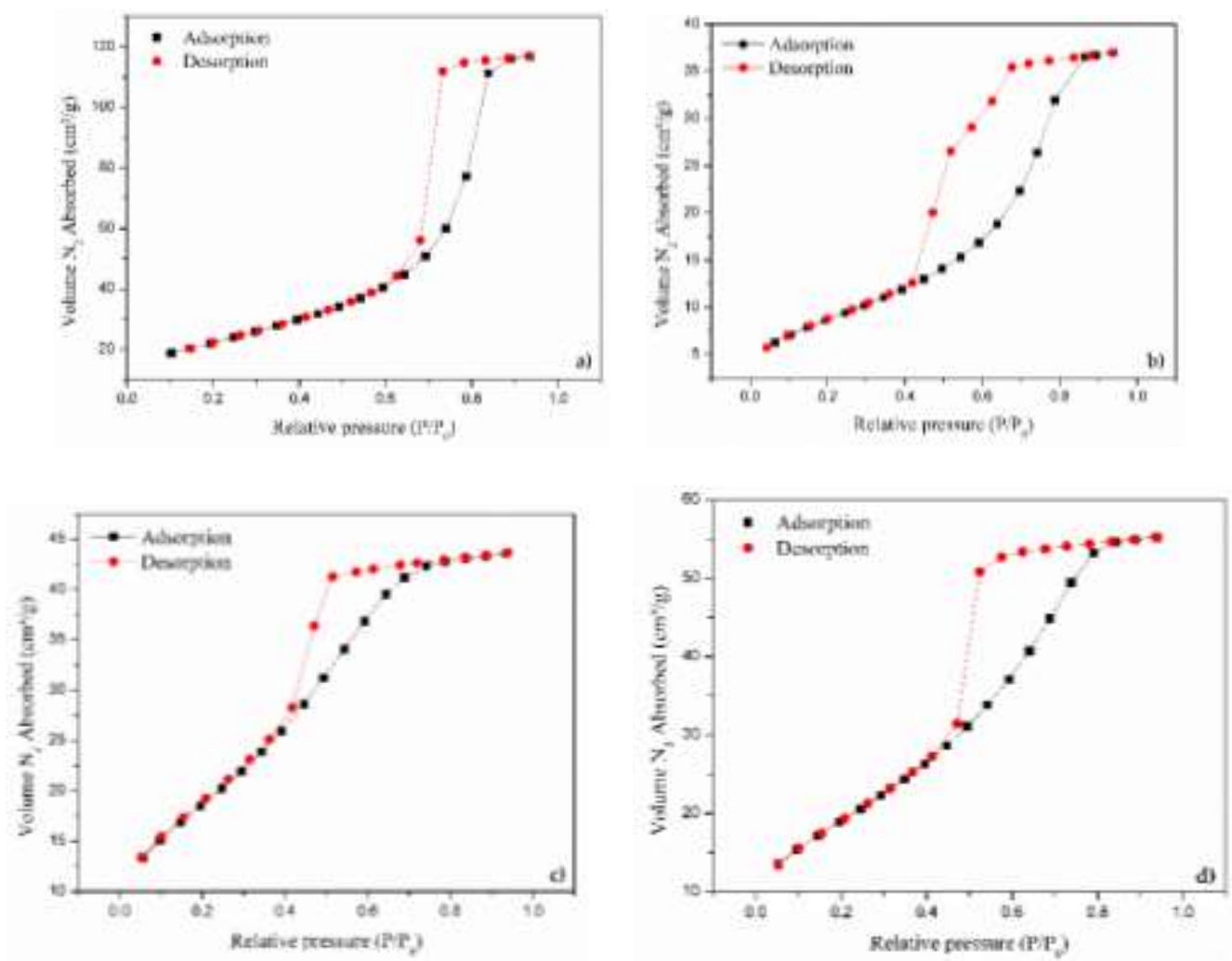

Figure 5. $\mathrm{N}_{2}$ adsorption-desorption isotherms for different catalyst samples: a) $\mathrm{TiO}_{2}-400{ }^{\circ} \mathrm{C}$, b) $2 \% \mathrm{Zn} / \mathrm{TiO}_{2}-$ $400{ }^{\circ} \mathrm{C}$, c) $6 \% \mathrm{Zn} / \mathrm{TiO}_{2}-300{ }^{\circ} \mathrm{C}$ and d) $10 \% \mathrm{Zn} / \mathrm{TiO}_{2}-400{ }^{\circ} \mathrm{C}$.

The isotherms resembled the Type IV isotherm with $\mathrm{H}$-II desorption hysteresis loop, based on IUPAC classification, which confirms the presence of mesoporous structure (20-500 Aं) [13-15]. Table 3 presents the surface area data of all materials, as well the volume and mean pore diameter. 
Table 3. $S_{o}, V_{p}$ and $d_{p}$ values of the synthesized catalysts.

\begin{tabular}{ccccc}
\hline Catalysts & $\begin{array}{c}\text { Calcination } \\
\text { temperature }\end{array}$ & $\mathbf{S}_{\mathbf{o}}\left(\mathbf{m}^{2} \mathbf{g}\right)$ & $\mathbf{V}_{\mathbf{p}}\left(\mathbf{c m}^{\mathbf{3}} \mathbf{g}\right)$ & $\mathbf{d}_{\mathbf{p}}(\dot{\mathbf{A}})$ \\
\hline \multirow{2}{*}{$\mathrm{TiO}_{2}$} & non-calcined & 272.0 & 0.23 & 16.92 \\
& $200^{\circ} \mathrm{C}$ & 204.0 & 0.23 & 22.59 \\
& $300^{\circ} \mathrm{C}$ & 130.1 & 0.22 & 33.93 \\
& $400^{\circ} \mathrm{C}$ & 81.3 & 0.18 & 45.09 \\
$2 \% \mathrm{Zn} / \mathrm{TiO}_{2}$ & non-calcined & 199.5 & 0.11 & 11.02 \\
& $200^{\circ} \mathrm{C}$ & 32.8 & 0.01 & 27.84 \\
& $400^{\circ} \mathrm{C}$ & 28.9 & 0.06 & 35.36 \\
$6 \% \mathrm{Zn} / \mathrm{TiO}_{2}$ & non-calcined & 316.5 & 0.18 & 11.42 \\
& $300^{\circ} \mathrm{C}$ & 70.1 & 0.07 & 10.38 \\
$10 \% \mathrm{Zn} / \mathrm{TiO}_{2}$ & non-calcined & 206.3 & 0.11 & 10.89 \\
& $200^{\circ} \mathrm{C}$ & 163.0 & 0.09 & 24.11 \\
\hline
\end{tabular}

For all the catalysts, there was a decrease of the surface area with the increase of the calcination temperature, due to the agglomeration of the particles. It was also observed that with the increase of the calcination temperature, the pore diameter of all the catalysts also increased.

\section{Scanning electron microscopy with energy dispersive x-ray}

Figure 6 shows the SEM micrographs of the calcined and non-calcined catalysts.
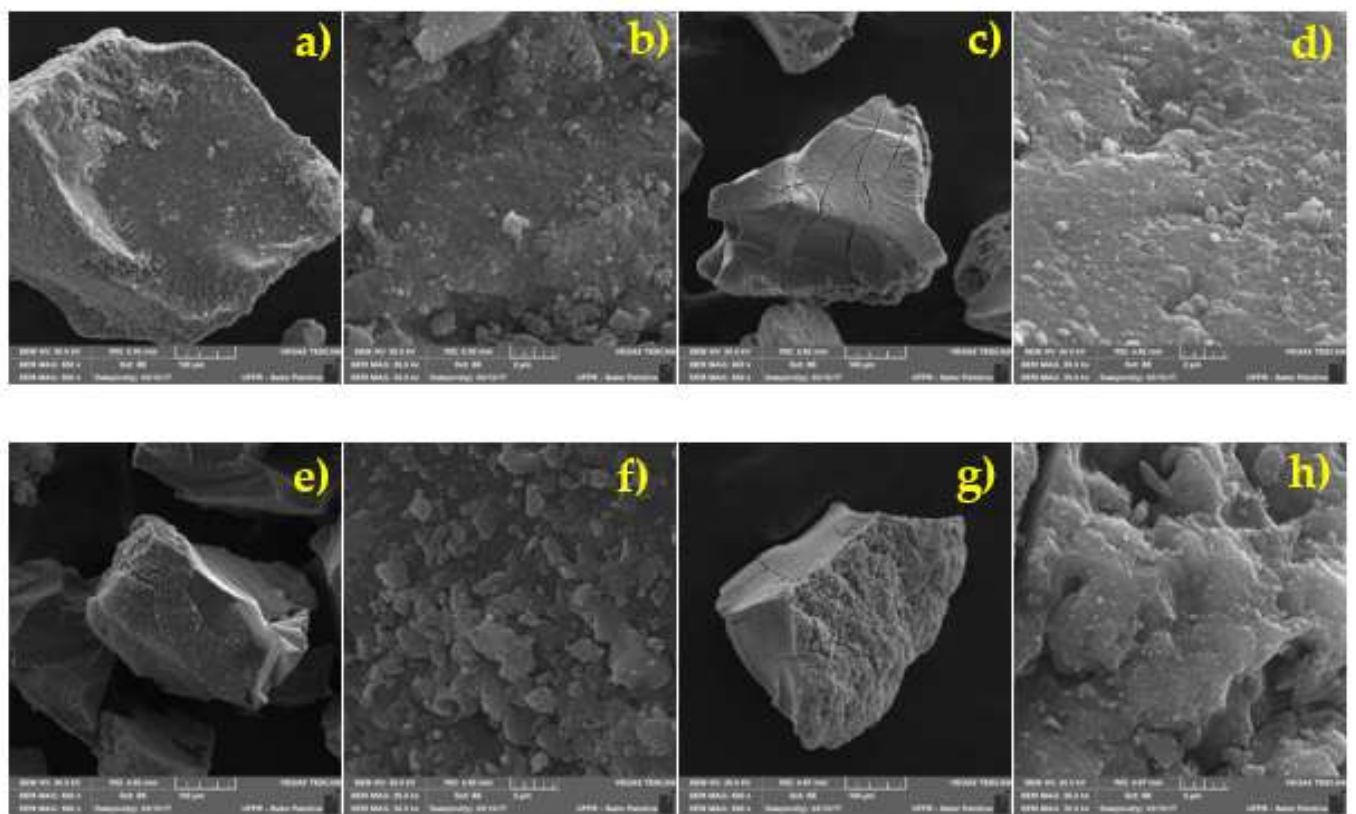

Figure 6. Scanning electron micrographs of $\mathrm{TiO}_{2}-400{ }^{\circ} \mathrm{C}$ in a) increase: $500 \mathrm{x}$ and b) increase: $2.000 \mathrm{x}, 2 \% \mathrm{Zn} / \mathrm{TiO}_{2}$ - $400{ }^{\circ} \mathrm{C}$ in c) increase: $500 \mathrm{x}$ and d) increase: $2.000 \mathrm{x}, 6 \% \mathrm{Zn} / \mathrm{TiO}_{2}-300{ }^{\circ} \mathrm{C}$ in e) increase: $500 \mathrm{x}$ and f) increase: $2.000 \mathrm{x}$, and $10 \% \mathrm{Zn} / \mathrm{TiO}_{2}-400{ }^{\circ} \mathrm{C}$ in g) increase: $500 \mathrm{x}$ and $\mathrm{h}$ ) increase: $2.000 \mathrm{x}$.

From Figure 6, it was possible to observe that the surface of the catalysts is rough, characteristic of solgel synthesis. Table 4 shows the EDS concentration results for $\mathrm{Zn}$ in the catalysts under study. Those results corroborate with the proportions proposed during the experiment.

Table 4. Analysis of EDS.

\begin{tabular}{cc}
\hline Catalysts & Zn (wt\%) \\
\hline $2 \% \mathrm{Zn} / \mathrm{TiO}_{2}$ & 2.06 \\
$6 \% \mathrm{Zn} / \mathrm{TiO}_{2}$ & 5.46 \\
$10 \% \mathrm{Zn} / \mathrm{TiO}_{2}$ & 10.09 \\
\hline
\end{tabular}




\section{X-ray diffraction}

In Figure 7, all present peaks at $25^{\circ}, 38^{\circ}, 48^{\circ}, 54^{\circ}, 55^{\circ}, 63^{\circ}$ and $70^{\circ}$ are related to the presence of anatase phase (tetragonal) of TiO2, according JCPDS card $n^{\circ}$ 84-1285 [16] without showing peaks related to the presence of other phases such as rutile and brookite.

It is known that the ionic radius of $\mathrm{Zn}^{2+}$ ions are higher than those of $\mathrm{Ti}^{4+}$ ions $\left(\mathrm{Zn}^{2+}: 74 \mathrm{pm}, \mathrm{Ti}^{4+}: 68 \mathrm{pm}\right)$. An increase in lattice parameters and cell volume is expected if the $\mathrm{Zn} 2+$ ions replace the $\mathrm{Ti}^{4+}$ ions in the lattice. However, it was possible to observe that the position of the peaks in Figure 7 remains unchanged, as do the lattice parameters and cell volume (Table 5) when compared with $\mathrm{TiO}_{2}$. Thus, it can be concluded that the $\mathrm{Zn}^{2+}$ ions are not doped in the interstices of the $\mathrm{TiO}_{2}$ lattice, possibly because they are highly dispersed in the material [17].

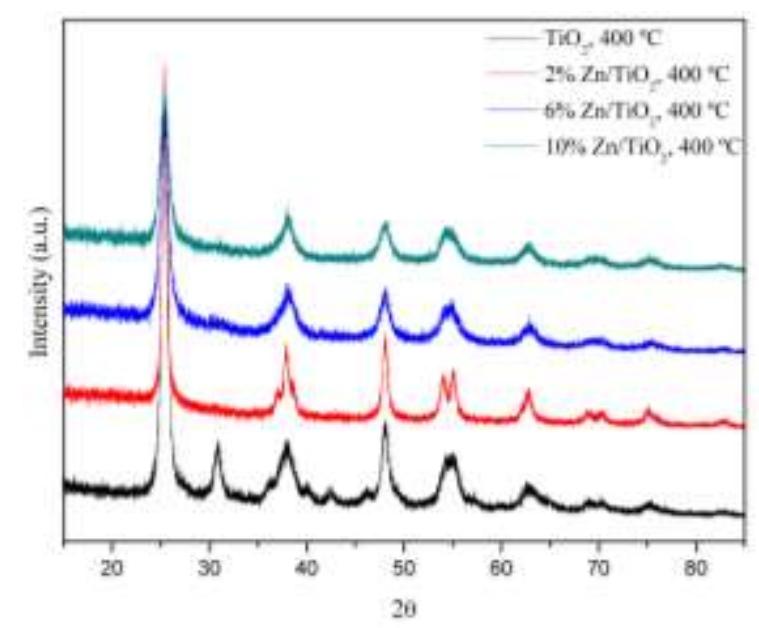

Figure 7. X-ray diffraction patterns for $\mathrm{TiO}_{2}$ and $\mathrm{Zn} / \mathrm{TiO}_{2}$ catalysts with $2 \%, 6 \%$ and $10 \% \mathrm{Zn}$ loading.

Table 5. Lattice parameters and cell volume.

\begin{tabular}{ccccc}
\hline Catalysts & A & $\begin{array}{c}\text { Lattice parameters } \\
(\dot{\mathbf{A}})\end{array}$ & & $\begin{array}{c}\text { Cell volume } \\
\left(\dot{\mathbf{A}}^{3}\right)\end{array}$ \\
& $\mathbf{B}$ & $\mathbf{C}$ & \\
\hline $\mathrm{TiO}_{2}-400{ }^{\circ} \mathrm{C}$ & 3.78 & 3.78 & 9.51 & 135.88 \\
$2 \% \mathrm{Zn} / \mathrm{TiO}_{2}-400^{\circ} \mathrm{C}$ & 3.78 & 3.78 & 9.51 & 135.88 \\
$6 \% \mathrm{Zn} / \mathrm{TiO}_{2}-300{ }^{\circ} \mathrm{C}$ & 3.78 & 3.78 & 9.51 & 135.88 \\
$10 \% \mathrm{Zn} / \mathrm{TiO}_{2}-400{ }^{\circ} \mathrm{C}$ & 3.78 & 3.78 & 9.51 & 135.88 \\
\hline
\end{tabular}

\section{Point of zero charge}

Table 6. shows the results of the PZC analysis found for the catalysts under study. The aqueous solution of reactive Orange-122 dye at $10 \mathrm{mg} \mathrm{L}-1$ has a $\mathrm{pH}$ PZC of about 6.0 .

Table 6. PZC results.

\begin{tabular}{ccc}
\hline Catalysts & $\begin{array}{c}\text { Calcination } \\
\text { temperature }\end{array}$ & pH \\
\hline & $200^{\circ} \mathrm{C}$ & 3.08 \\
$\mathrm{TiO}_{2}$ & $300^{\circ} \mathrm{C}$ & 5.81 \\
& $400^{\circ} \mathrm{C}$ & 5.63 \\
$2 \% \mathrm{Zn} / \mathrm{TiO}_{2}$ & $200^{\circ} \mathrm{C}$ & 3.72 \\
$6 \% \mathrm{Zn} / \mathrm{TiO}_{2}$ & $400^{\circ} \mathrm{C}$ & 5.98 \\
$10 \% \mathrm{Zn} / \mathrm{TiO}_{2}$ & $300^{\circ} \mathrm{C}$ & 5.50 \\
& $200^{\circ} \mathrm{C}$ & 4.34 \\
\hline
\end{tabular}

The point of zero charge, which evaluates the behavior of the surface of catalysts in aqueous solutions, can suggest the tendency of the surface of a material as to its acidity or basicity, indicating that the material is negatively or positively charged, when in solution where the $\mathrm{pH}$ is higher or lower than its $\mathrm{pH}_{\text {Pzc }}$, respectively [18]. In this process, the $\mathrm{pH}$ in which the photocatalytic test occurs affects the charge of the catalyst surface and consequently the adsorption of pollutants. 
It was possible to observe that for all the catalysts, the $\mathrm{pH}$ values are below $\mathrm{pH}$ pzc (Table 6). Consequently, the surfaces of the catalysts are positively charged.

\section{Photocatalytic tests}

\section{Dye discoloration under sunlight}

Figure 8 shows the photocatalytic discoloration of aqueous solution of reactive Orange-122 dye under solar light in reaction time of 2 hours.
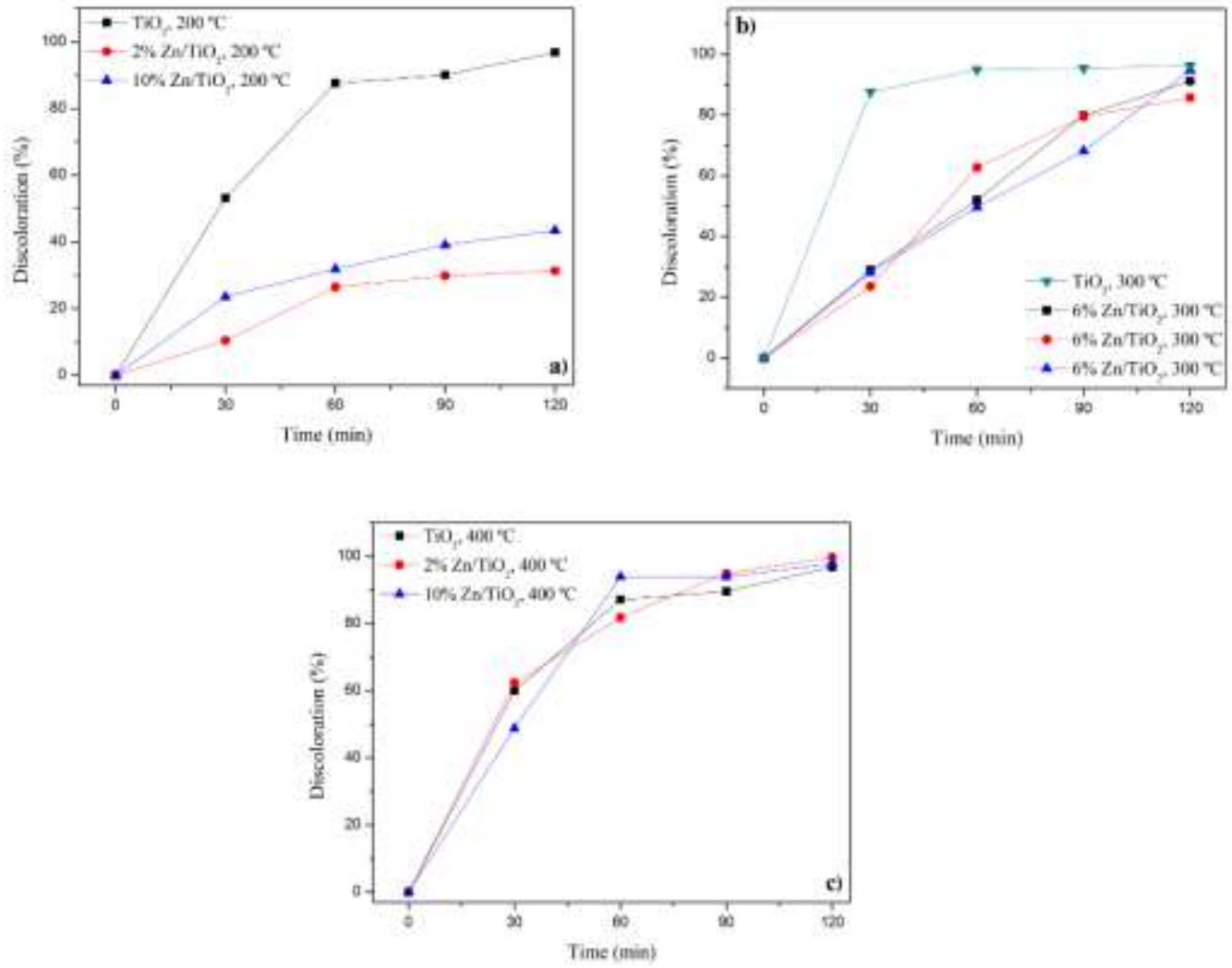

Figure 8. Photocatalytic discoloration (\%) of aqueous solution of reactive Orange-122 dye with $\mathrm{Zn} / \mathrm{TiO}{ }_{2}$ calcined catalysts: a) calcined at $200^{\circ} \mathrm{C}$, b) calcined at $300^{\circ} \mathrm{C} \mathrm{e} \mathrm{c}$ ) calcined at $400{ }^{\circ} \mathrm{C}$.

Overall, the calcination temperature of $400^{\circ} \mathrm{C}$ presented as more effective in discoloration. It was also evident that for the catalysts calcinated at $200{ }^{\circ} \mathrm{C}$, an increase in the metallic charge of zinc from 2 to $10 \%$ promoted an increase in the discoloration, this occurred thanks to an increase in the surface area of the catalyst, which with a greater doping of zinc was able to promote a better discoloration.

However, the TiO2 catalysts presented higher values of discoloration compared with the catalysts doped with zinc, probably because they have a larger surface area as evidenced by B.E.T.

\section{Discoloration kinetics}

The results obtained for the discoloration kinetics using the Langmuir-Hinshelwood pseudo-first-order equation are shown in Figure 9, and the pseudo-first-order constants and determination coefficients (R2) are shown in Table 7. 

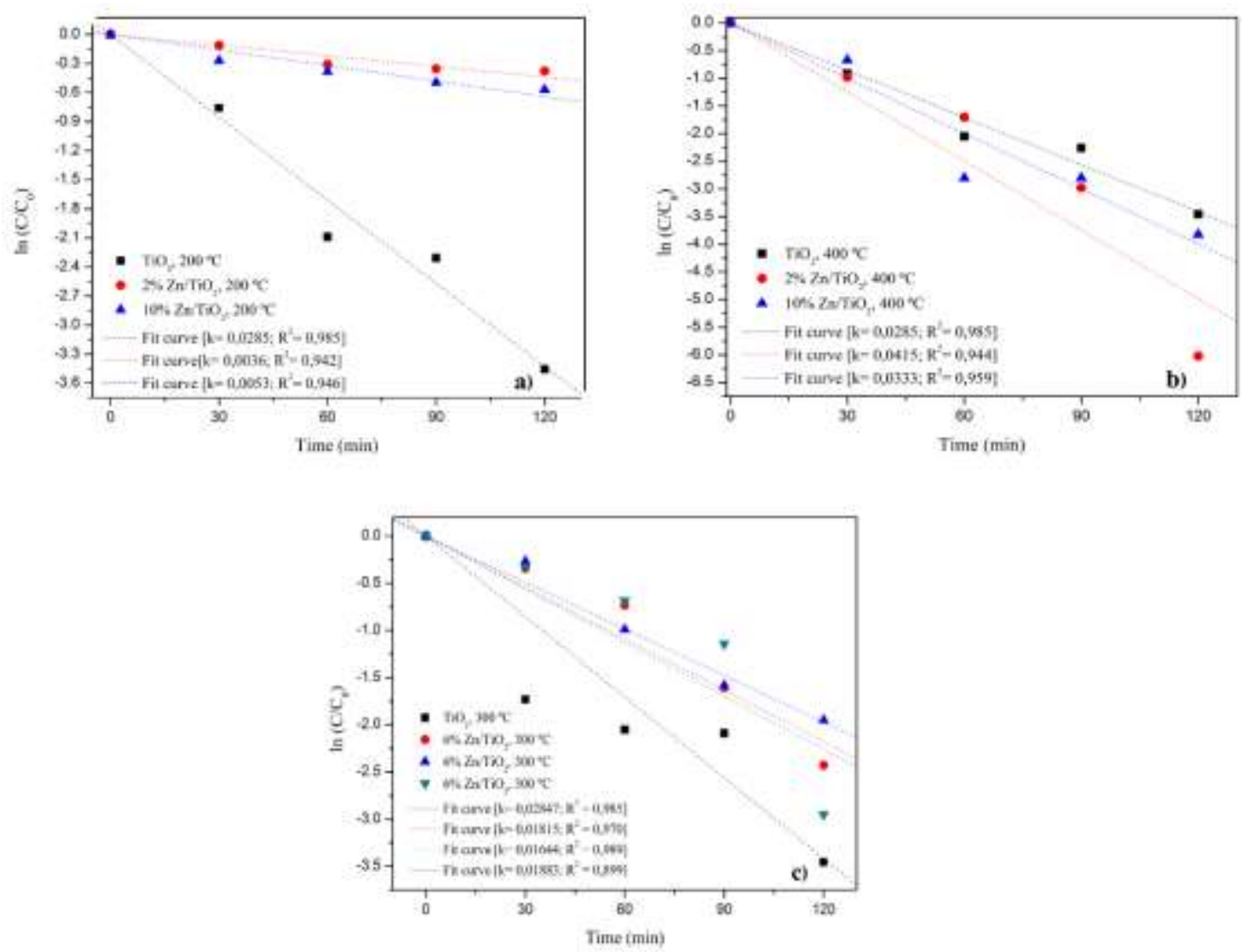

Figure 9. Kinetic model adjustment of aqueous solution of reactive Orange-122 dye with $\mathrm{Zn} / \mathrm{TiO}_{2}$ calcined catalysts: a) calcined at $200^{\circ} \mathrm{C}$, b) calcined at $400^{\circ} \mathrm{C}$ and c) calcined at $300^{\circ} \mathrm{C}$.

It was possible to observe that the linearized Langmuir-Hinshelwood pseudo-first-order model accorded well with the experimental data at the three temperatures analyzed, and the highest determination coefficients were observed for $\mathrm{TiO} 2$ catalysts.

Increasing the calcination temperature has a positive effect on the pseudo-first-order kinetic constant of this model. It is also possible to verify an increase of the kinetic constant with the increase of the calcination temperature during the photocatalytic reaction.

Table 7. Pseudo-first-order rate constants of $\mathrm{Zn} / \mathrm{TiO}_{2}$ catalysts at different calcination temperature.

\begin{tabular}{cccc}
\hline $\begin{array}{c}\text { Calcination } \\
\text { Temperature }\end{array}$ & Catalyst & $\mathbf{k}\left(\mathbf{m i n}^{-1}\right)$ & $\mathbf{R}^{\mathbf{2}}$ \\
\hline \multirow{2}{*}{$200{ }^{\circ} \mathrm{C}$} & $\mathrm{TiO}_{2}$ & 0.0200 & 0.985 \\
& $2 \% \mathrm{Zn} / \mathrm{TiO}_{2}$ & 0.0036 & 0.942 \\
& $10 \% \mathrm{Zn} / \mathrm{TiO}_{2}$ & 0.0053 & 0.946 \\
& $\mathrm{TiO}_{2}$ & 0.0250 & 0.985 \\
$300{ }^{\circ} \mathrm{C}$ & $6 \% \mathrm{Zn} / \mathrm{TiO}_{2}(\mathrm{I})$ & 0.0181 & 0.970 \\
& $6 \% \mathrm{Zn} / \mathrm{TiO}_{2}(\mathrm{II})$ & 0.0164 & 0.989 \\
& $6 \% \mathrm{Zn} / \mathrm{TiO}_{2}(\mathrm{III})$ & 0.0183 & 0.899 \\
& $\mathrm{TiO}_{2}$ & 0.0285 & 0.985 \\
$400{ }^{\circ} \mathrm{C}$ & $2 \% \mathrm{Zn} / \mathrm{TiO}_{2}$ & 0.0415 & 0.944 \\
& $10 \% \mathrm{Zn} / \mathrm{TiO}_{2}$ & 0.0333 & 0.959 \\
\hline
\end{tabular}

\section{Statistical analysis}

Through statistical analysis, it was possible to observe that the effect of the calcination temperature significantly influenced the degree of discoloration of the dye, since a p-value $<0.05$ was obtained, as presented in Table 8. The residual error was $\sqrt{20.52}=4.53$ (see the value in column 5 , row 7 of Table 8). 
Table 8. ANOVA results for the quadratic model of response surface.

\begin{tabular}{|c|c|c|c|c|c|c|}
\hline \multirow[b]{2}{*}{ Source } & \multirow[b]{2}{*}{ Effects } & \multirow[b]{2}{*}{ DF } & \multicolumn{4}{|c|}{ Discoloration } \\
\hline & & & $\begin{array}{l}\text { Sum of } \\
\text { squares }\end{array}$ & Mean square & $F$ value & p-value \\
\hline Temperature & 61.41 & 1 & 3771.19 & 3771.19 & 183.78 & 0.0054 \\
\hline $\mathrm{Zn}$ & 5.10 & 1 & 26.01 & 26.01 & 1.27 & 0.3772 \\
\hline Temperature ${ }^{2}$ & - & 1 & 866.70 & 866.70 & 42.24 & 0.0229 \\
\hline Zn x Temperature & -7.04 & 1 & 49.56 & 49.56 & 2.41 & 0.2604 \\
\hline Residual & - & 2 & 41.04 & 20.52 & & \\
\hline Total & - & 6 & 4754.50 & 792.42 & & \\
\hline & & & $R^{2}=0.9914$ & $\mathrm{R}^{2} \mathrm{adj}=0.9741$ & & \\
\hline
\end{tabular}

The results of the effects of the main factors, $\mathrm{Zn}$ and calcination temperature, are given in Table 8 and shown in Figure 10.

In Figure 10, the vertical axes represent the mean values of percentage of discoloration of the dye, and the horizontal axes represent the levels of the factors $\mathrm{Zn}(\%)$ and calcination temperature $\left({ }^{\circ} \mathrm{C}\right)$, respectively. Note that $\mathrm{Zn}(\%)$ content has practically no significant effect on dye discoloration, once the mean percentage of discoloration at the lower concentration level $(2 \%)$ is close to the mean percentage of discoloration at the higher concentration level (10\%).

However, it is observed that the effect of the calcination temperature $\left({ }^{\circ} \mathrm{C}\right)$ is strongly significant, since the average percentage of discoloration in the lower temperature level, whose value was $37.38 \%$, is much lower than the percentage of discoloration in the higher temperature level, whose value was $98.79 \%$.

Since the interesting problem is to maximize the percentage of dye discoloration, Figure 10 indicates that it would be best to adjust the calcination temperature to a higher level, because the ascending slope of the line indicates that the higher the temperature $\left({ }^{\circ} \mathrm{C}\right)$, the higher is the percentage of discoloration of the dye.
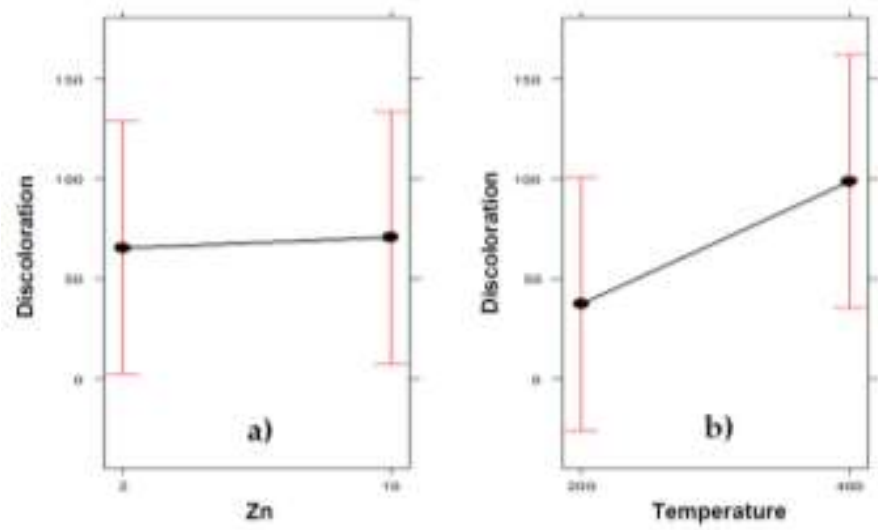

Figure 10. Effect of the main factors analyzed.

It is also noted, both through the ANOVA test (Table 8) and Figure 11, that there is weak statistical evidence that the interaction between the $\mathrm{Zn}(\%)$ content and the calcination temperature has an effect on the process of dye discoloration. In Figure 11, the horizontal axis represents the temperature levels $\left({ }^{\circ} \mathrm{C}\right)$, and the vertical axis represents the average percentage of dye discoloration.

The dotted line on the graph (Figure 11) represents all coordinate pairs (Temperature, Discoloration) for the lower concentration level of $\mathrm{Zn}(\%)$, and the red straight line represents all pairs of coordinates (Temperature, Discoloration) for the higher concentration level of $\mathrm{Zn}(\%)$. Thus, it is observed that the best fit would be to fix the calcination temperature at the high level $\left(400{ }^{\circ} \mathrm{C}\right)$ and the $\mathrm{Zn}$ concentration at the low level $(2 \%)$, which would obtain an expected value of $99.76 \%$ discoloration. 


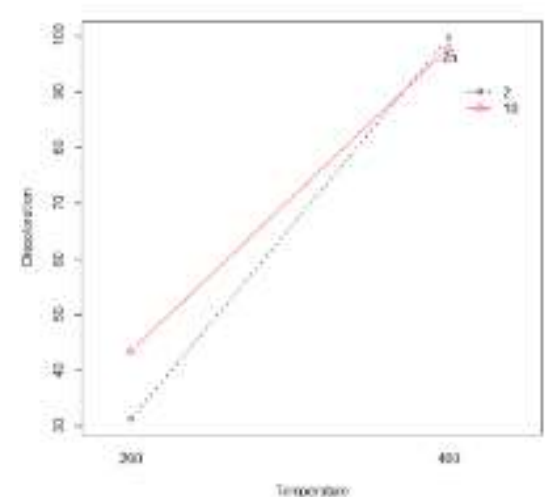

Figure 11. $\mathrm{Zn} \times$ Calcination Temperature interaction.

Finally, a second-order response surface model was obtained by using ordinary least squares. The regression model with an adjusted regression coefficient $\left(R^{2}\right.$ adj $\left.=0.9741\right)$ is represented by Equation $(5)$.

$$
\mathrm{y}=-0.0022 \mathrm{x}_{2}^{2}+3.2755 \mathrm{x}_{1}+1.7090 \mathrm{x}_{2}-0.0088 \mathrm{x}_{1} \mathrm{x}_{2}-231.355
$$

Being $x 1$ the concentration of $\mathrm{Zn}(\%)$; $\mathrm{x} 2$ calcination temperature $\left({ }^{\circ} \mathrm{C}\right)$ and $\mathrm{y}$ the percentage of dye discoloration.

Figure 12 shows the level curves (a) and the response surface (b) obtained. The figure shows that, in fact, the optimal fit that maximizes the percentage of dye discoloration is obtained by fixing the concentration of $\mathrm{Zn}$ at $2 \%$ and calcination temperature at a level of $400{ }^{\circ} \mathrm{C}$, which would give an expected percentage of discoloration of $99.76 \%$.
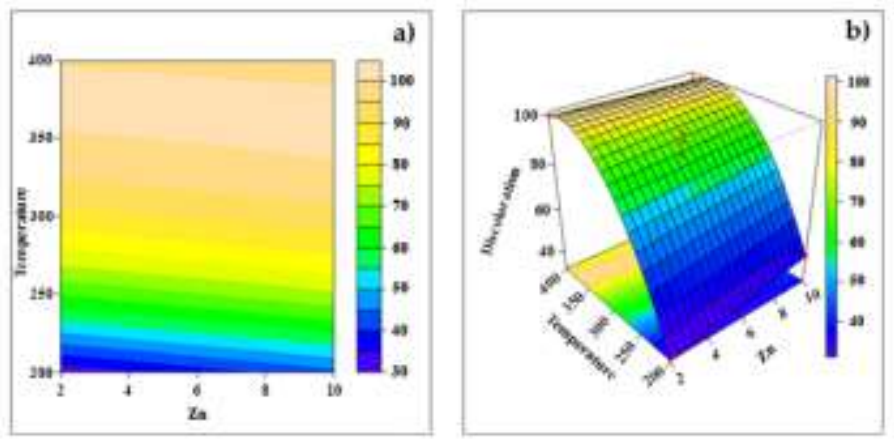

Figure 12. Response surface showing the effect of the variables on the dye discoloration.

\section{Dye degradation}

Before the degradation experiment it was performed DI-ESI-MS, the electrospray-mass spectrometric (ESI-MS) analysis of the dye obtained from a textile industry of the region was carried out. The dye was declared as reactive Orange-122. Figure 13 shows the mass spectrum of the solution of the dye found by using an aqueous solution of the dye diluted in methanol and formic acid, scanned from m/z 50 to m/z 1200 in positive ion mode.

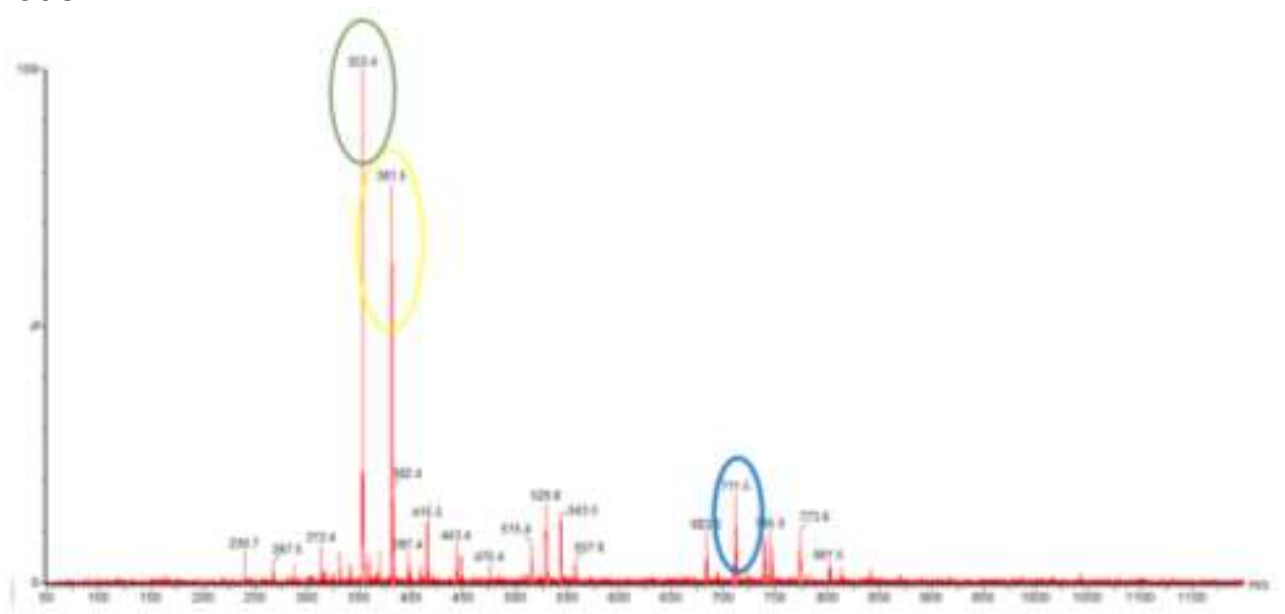

Figure 13. Mass spectrum obtained for the solution of the reactive Orange-122 dye donated by the textile industry. 
The sodiated molar mass of reactive Orange-122 dye is $1034.3 \mathrm{~g} \mathrm{~mol}-1$ and the exact mass $1032.9 \mathrm{Da}$. It is not unusual to observe in positive electrospray mass spectrometry the molecules with sodium replaced by protons with one more proton or sodium to cationize them. The mass spectrometer used was equipped with unit resolution quadrupole analyzers. Hence, the expected species could be of $\mathrm{m} / \mathrm{z} 946[\mathrm{M}+\mathrm{H}]+$, of $\mathrm{m} / \mathrm{z}$ $968[\mathrm{M}-\mathrm{Na}++\mathrm{H}]+$, of $\mathrm{m} / \mathrm{z} 990[\mathrm{M} 2-2 \mathrm{Na}++\mathrm{H}]+$, of $\mathrm{m} / \mathrm{z} 1012[\mathrm{M} 3-3 \mathrm{Na}++\mathrm{H}]+$ and of m/z $1034[\mathrm{M} 4-4 \mathrm{Na}++\mathrm{H}]+$.

Considering the species that might be present with a solution of Orange-122, none of them was observed. It was concluded that the product coming from the industry was previously degraded. It was noticed that a cation of $\mathrm{m} / \mathrm{z} 711$ may be attributed as a degraded form, and Figure 14 suggests a degradation mechanism by loss of a neutral molecule of $281 \mathrm{u}$ that matches a part of the precursor Orange-122. The proposed degraded product of $\mathrm{m} / \mathrm{z} 711$ contains the chromophores that would be active in UV-vis experiments. Figure 13 shows that the degradation products of $\mathrm{m} / \mathrm{z} 381$ and $\mathrm{m} / \mathrm{z} 353$ match the degradation mechanism proposed in Figure 14.

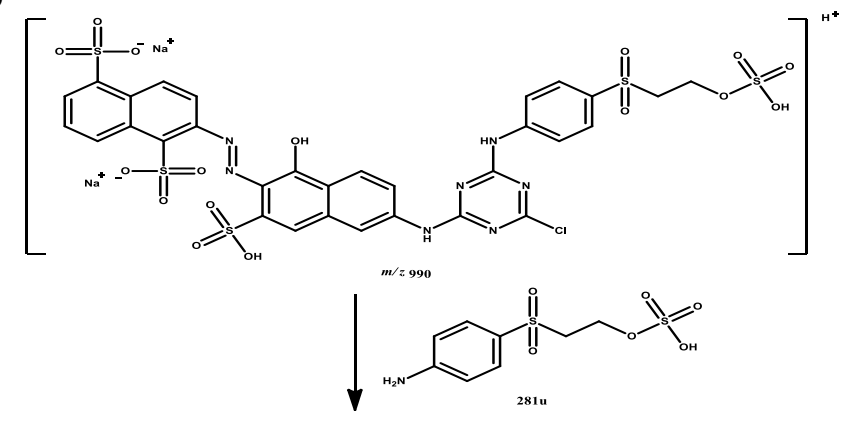

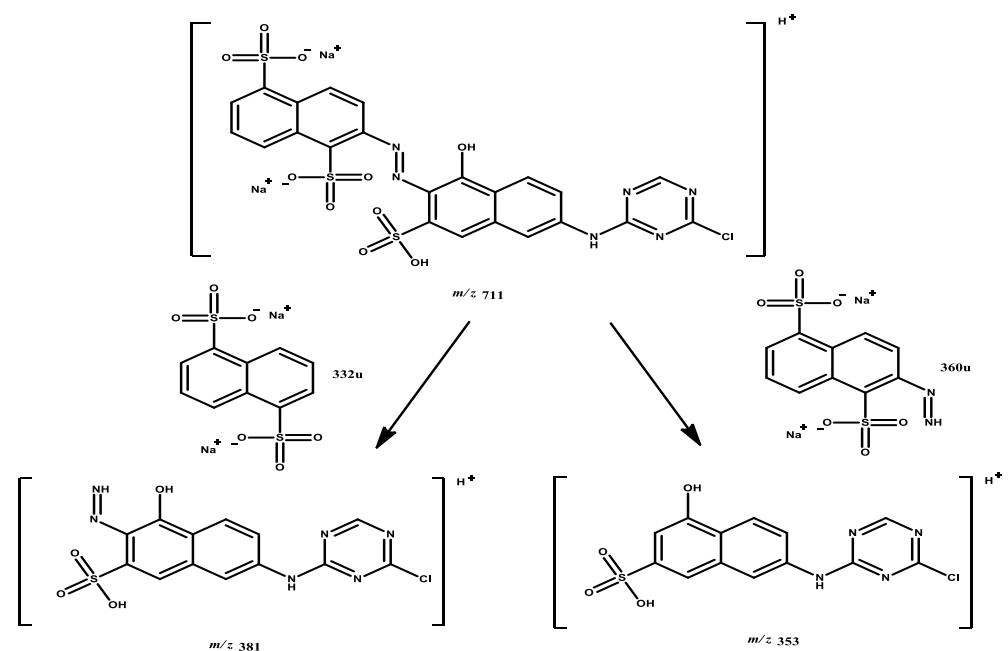

Figure 14. Degradation mechanism of Orange-122 proposed.

The ions of $\mathrm{m} / \mathrm{z} 353$ and 381 possibly do not present color since the electron resonance among two aromatic moieties was lost, as proposed in the mechanism. The ion of $\mathrm{m} / \mathrm{z} 711$ was used as the target to monitor the degradation of the dye by using the mass spectrometer. Figure 15 shows the kinetic of degradation of the ion of $\mathrm{m} / \mathrm{z} 711$.
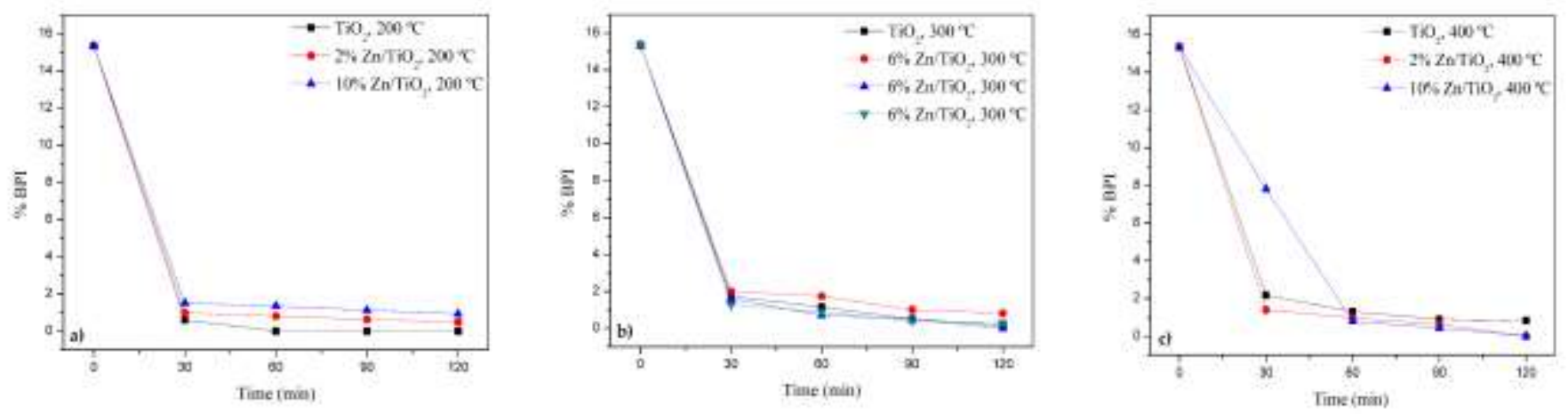

Figure 15. Degradation (m/z 711.6) for catalysts calcined at: a) $200^{\circ} \mathrm{C}$, b) $300^{\circ} \mathrm{C}$ and c) $400{ }^{\circ} \mathrm{C}$. 
Figure 15 shows that the ion of $\mathrm{m} / \mathrm{z} 711$ had its abundance decreased during the reaction. All catalysts in the reaction time of $60 \mathrm{~min}$ degraded the ion of $\mathrm{m} / \mathrm{z} 711$ to less than $2 \%$ of abundance, and with the reaction time of $120 \mathrm{~min}$ almost $100 \%$ was degraded, showing that the reaction was complete and the photocatalytic methods were efficient. After the degradation using the catalysts, the observed mass spectra were similar. Figure 16 shows a representative mass spectrum obtained after the degradation with all catalysts.

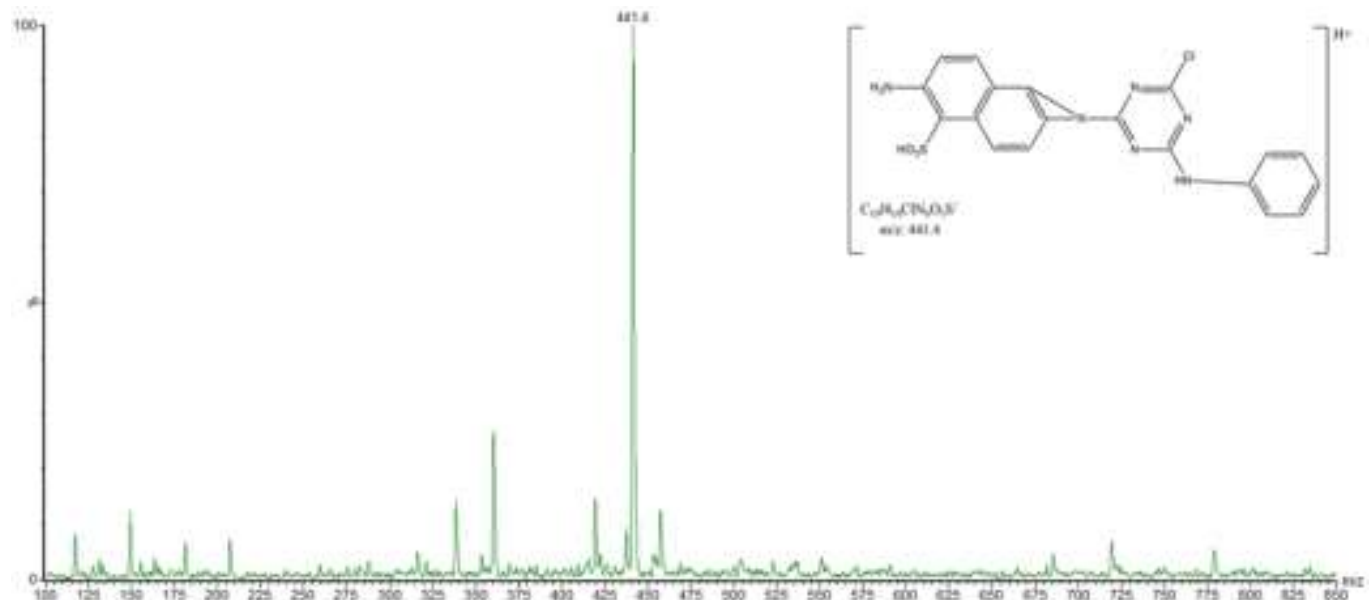

Figure 16. Mass spectrum for the catalyst $2 \% \mathrm{Zn} / \mathrm{TiO}_{2}$ calcined at $400{ }^{\circ} \mathrm{C}$, on the reaction time of 120 min, and the proposed structure of the formed degraded product of $\mathrm{m} / \mathrm{z} 441$.

The proposed structure of the degraded product of $\mathrm{m} / \mathrm{z} 441$ does not present azo moiety and corroborates the loss of color through the photocatalytic process, verified by using a wavelength of $486 \mathrm{~nm}$, resulting in $99.76 \%$ discoloration. The degradation of the product that came from the textile industry, declared as Orange-122, resulted in secondary products without total mineralization of the textile effluent, even with the total discoloration observed.

\section{CONCLUSION}

The results obtained from the photocatalytic tests showed that the addition of zinc in titanium, as well as the calcination temperatures used, influence the discoloration of aqueous solution of reactive Orange-122 dye. In general, TiO2 supports presented higher values of discoloration when compared to the zinc-doped catalysts. It can also be concluded that higher calcination temperatures have a significant and favorable effect on the speed of the photocatalysis reaction of the textile dye.

The optimal adjustment that maximized the percentage of dye discoloration was with a percentage of 2 $\%$ of $\mathrm{Zn}$ and calcination temperature of $400{ }^{\circ} \mathrm{C}$, which generated discoloration values of $99.76 \%$.

The catalysts in the reaction time of $2 \mathrm{~h}$ were unable to mineralize the dye to innocuous compounds, generating intermediate degradation products such as the $\mathrm{m} / \mathrm{z}$ ion of 441.4 .

Acknowledgments: The authors wish to thank Simepar by insolation data of the solar irradiation.

Conflicts of Interest: The authors declare no conflict of interest.

\section{REFERENCES}

1. Medina JC, Bizarro M, Silva-Bermudez P, Giorcelli M, Tagliaferro A, Rodil SE. Photocatalytic discoloration of methyl orange dye by $\delta$-Bi2O3 thin films. Thin Solid Films. 2016; 612:72-81.

2. Khan SB, Hou M, Shuang S, Zhang Z. Morphological influence of TiO2 nanostructures (nanozigzag, nanohelics and nanorod) on photocatalytic degradation of organic dyes. Appl Surf Sci. 2017; 400:184-93.

3. Colpini LMS, Lenzi GG, Urio MB, Kochepka DM, Alves HA. Photodiscoloration of textile reactive dyes on Ni/TiO2 prepared by the impregnation method: Effect of calcination temperature. J Environ Chem Eng. 2014; 2:2365-2371.

4. Rodrigues CSD, Carabineiro SAC, Maldonado-Hódar FJ, Madeira LM. Wet peroxide oxidation of dye-containing wastewaters using nanosized Au supported on Al2O3. Catal Today. 2017; 280(1):165-75.

5. Tang $\mathrm{C}$, Chen V. The photocatalytic degradation of reactive black 5 using TiO2/UV in an annular photoreactor. Water Res. 2004; 38:2775-81.

6. Gogate PR, Pandit AB. A review of imperative technologies for wastewater treatment I: oxidation technologies at ambient conditions. Adv. Environ. Res. 2004; 8:501-51. 
7. Augugliaro V, Litter M, Palmisano L, Soria JJ. The combination of heterogeneous photocatalysis with chemical and physical operations: A tool for improving the photoprocess performance. Photochem. Photobiol., C. 2006;7:12744.

8. Silva SS, Magalhaes F, Sansiviero MTC. Nanocomposites semiconductors ZnO/TiO2: Photocatalytic tests. Quím. Nova. 2010; 33(1):85-9. (In Portuguese).

9. Colpini LMS, Alves HJ, Santos OAA, Costa CMM. Discoloration and degradation of textile dye aqueous solutions with titanium oxide catalysts obtained by the sol-gel method, Dyes Pigm. 2008; 76:525-9.

10. Lenzi GG, Lenzi MK, Baesso ML, Bento AC, Jorge LMM, Santos OAA. Cobalt, nickel and ruthenium-silica based materials synthesized by the sol-gel method, J Non Cryst Solids. 2008; 354:4811-5.

11. Das D, Mishra HK, Parida KM, Dalai AK. Preparation, physico-chemical characterization and catalytic activity of sulphated ZrO2-TiO2 mixed oxides. J. of Molecular Catal. A: Chemistry. 2002; 189:271-82.

12. Dong T, Tong J, Bian C, Sun J, Xia S. Experimental study and kinetic analysis of oxidant-free thermal-assisted UV digestion utilizing supported nano-TiO2 photocatalyst for detection of total phosphorous. Chinese $\mathrm{J}$ Chem Eng. 2015; 23:93-9.

13. Sawangphruk M, Shiruk $P$, Chiocan $P$, Krittayavathananon A, Luanwuthi S, Limtrakul J. High-performance supercapacitor of manganese oxide/reduced graphene oxide nanocomposite coated on flexible carbon fiber paper. Carbon. 2013; 60:109-16.

14. Trejda M, Tuel A, Kujawa J, Ziolek M. Niobium rich SBA-15 materials - preparation, characterization and catalytic activity. Micropor Mesopor Mat. 2008; 110:271-8.

15. Amgarten DR. Determination of the specific pore volume of chromatographic silicas by desorption of excess liquids [master's thesis], Campinas: Campinas State University, Chemistry Institute; 2006. 80 p.

16. JCPDS, International Centre for Diffraction Data, PCPDFWIN, 1997.

17. Yan S, Yu Y, Gu Y, Liu Y, Cao Y. Improved photocatalytic activity of TiO2 modified with unique O-Zn-Cl surface species. Sep Purif Technol. 2016; 171:118-22.

18. Merg JC, Rosett F, Penha FG, Pergher SBC, Petkowicz DI, Santos JHZ. Incorporation of titanium dioxide into zeolites for use in heterogeneous photocatalysis. Quím. Nova. 2010; 33(7):1525-8.

2020 by the authors. Submitted for possible open access publication under the terms and conditions of the Creative Commons Attribution (CC BY NC) license (https://creativecommons.org/licenses/by-nc/4.0/). 